Науковий вісник Ужгородського університету

Серія Біологія, Випуск 46-47 (2019): 66-72

(C) Різничук Н.I., Миленька М.М., Гнєзділова В.I.,

Мельниченко Г.М. 2019

DOI: $10.24144 / 1998-6475.2019 .46-47.66-72$

\title{
АНАТОМІЧНІ ОСОБЛИВОСТІ БУДОВИ ГЕНЕРАТИВНИХ ОРГАНІВ ВИДІВ РОДУ POLYGONATUM MILL.
}

\author{
Н.І. Різничук ${ }^{1}$ М.М. Миленька ${ }^{2}$ В.І. Гнєзділова ${ }^{3}$, Г.М. Мельниченко ${ }^{4}$
}

Anatomical features of the generative organs structure of the Polygonatum Mill. species. - Riznychuk N.I., Mylenka M.M., Gniezdilova V.I., Melnichenko G.M. - For understanding the evolution of monocotyledons in general, data on the structure and development of the flower is still not used completely. There is no information about the morphogenesis of a flower and a complete description of its structure for many taxa of archaic monocotyledons. Thus, in the phylogenetic systematics of the Asparagaceae family, the ideas of monophyletic groups within the family was formed, but the links between them remain controversial. The primary task of monocotyledons taxonomy remains the implementation of an evolutionary-morphological analysis of the flower and coordination of the directions of molecular and morphological evolution. The species of the Polygonatum Mill. genus have strongly thickened base and roof of the ovary containing the basal and apical parts of the elongated septal nectary. The style in species with septal nectary is formed only by postgenital adhesion of carpels. The typical feature of the flower is six perianth leaves arranged into two circles, usually not differentiated into petals and sepals, six stamens placed into two circles and three carpels. The stamens are joined to the flower tube of the perianth. The ovules are always placed in the hemisimplicate zone of the gynaeceum in even numbers, two each, the base and the roof of the ovary are thickened. The investigated species do not have the hemisimplicate zone, but there are sinascidiate, hemisimplicate fertile and asymplicate zones. The septal nectary in the studied species is located along the entire ovary: from its base, above the cell to its roof. There is a direct relationship between the height of the ovary and the height of the septal nectar. The walls of the nectar slit are of a secretory nature, as are the walls of the body of the nectar. The representatives of the genus Polygonatum Mill. Have the nectar slit which in the radial direction reaches more than a half the length of the radius of the ovary.

Key words: gynaeceum, androecium, ovary, micropyle, pollen, ovule.

Addresses: Vasyl Stefanyk Precarpathian National University, str. Halytska, 201, Ivano-Frankivsk, Ukraine; e-mail: 1-nadja1986_24@ukr.net,2-mulenka.m@gmail.com,3-victoria1975@bigmir.net,4-gdutchak@ukr.net

Анатомічні особливості будови генеративних органів видів роду Роlygonatum Mill. - Різничук Н.I., Миленька М.М., Гнєзділова В.І., Мельниченко Г.М. - Для розуміння еволюиії однодольних в иілому дані про структуру і розвиток квітки до иього часу не використовуються в повному обсязі. Для багатьох таксонів архаїчних однодольних немає не лише інформації про морфогенез квітки, а й повного опису ї̈ будови. Таким чином, у філогенетичній систематиці родини Аsparagaceae, сформувалось уявлення про монофілетичні групи всередині родини, але зв'язки між ними залишаються спірними. Першочерговим завданням систематики однодольних залишається здійснення грунтовного еволючіийно-морфологічного аналізу квітки та узгодження напрямків молекулярної та морфологічної еволючії. У зав'язі видів роду Polygonatum Mill. наявні сильно потовщені основа $i$ дах зав'язі, які містять базальну та апікальну частини видовженого септального нектарника відповідно. Стовпчик у видів з септальним нектарником сформований лише за рахунок постгенітального злипання плодолистків. Типовою ознакою квітки є шість листочків оцвітини, розміщених у двох колах, як правило не диферениійовані на пелюстки $і$ чашолистки, шість тичинок у двох колах $i$ три плодолистки. Тичинки, прирослі до квіткової трубки оцвітини. Насінні зачатки розміщені завжди у гемісимплікатній зоні гінещея в парній кількості, по два, основа та дах зав'язі потовщені. У досліджуваних видів гемісимплікатна зона відсутня, наявні синасцидіатна, гемісимплікатна фертильна і асимплікатна зони. Септальний нектарник у досліджених видів розміщений вздовж иүілої зав 'язі: від ї̈ основи, вище гнізд до ї̈ даху. Спостерігається пряма залежність між висотою зав'язі $i$ висотою септального нектарника. Стінки нектарної шілини на всій довжині носять секреторний характер, як $i$ стінки тіла нектарника. У представників роду Polygonatum Mill. довжина нектарної щзілини в радіальному напрямку досягає більше половини довжини радіуса зав'язі.

Ключові слова: гінецей, андроцей, зав'язь, мікропіле, пилок, насінний зачаток.

Адреси: ДВНЗ «Прикарпатський національний університет ім. Василя Стефаника», вул. Галицька, 201, ІваноФранківськ, Україна; e-mail: 1 -nadja1986_24@ukr.net,2-mulenka.m@gmail.com,3-victoria1975@bigmir.net, 4 -gdutchak@ukr.net 


\section{Вступ}

В Україні зростає чотири види роду Polygonatum Mill., 3 яких найбільш поширена купина багатоквіткова (Polygonatum multiflorum (L.) All.). У лісових i чагарникових біотопах широко поширені також купина запашна (Polygonatum odoratum (Mill.) Druce.), купина широколиста (Polygonatum latifolium Desf.) та купина кільчаста (Polygonatum verticillatum (L.) All.). В умовах Передкарпаття значний науковий інтерес становлять представники аборигенної бореально-неморальної флори, чільне місце серед яких належить видам роду Polygonatum Mill. (Mosyakin, Fedoronchuk 1999). Еколого-ботанічна характеристика останніх $€$ неповною i обмеженою, переважно систематичними й ареалогічними описами. Літературні дані щодо морфо-анатомічних особливостей видів роду Polygonatum Mill. потребують уточнення (Riznychuk 2017).

\section{Матеріал та методи}

Вивчали види роду Polygonatum Mill.: Polygonatum multiflorum (L.) All., Polygonatum odoratum (Mill.) Druce., Polygonatum verticillatum (L.) All., Polygonatum latifolium Desf., які займають різні ділянки 3 широкою амплітудою умов місцезростання. Види роду Polygonatum Mill. відповідно до філогенетичної системи покритонасінних APG IV system (Angiosperm Phylogeny Group classification for the orders and families of flowering plants), a також даних The Plant List належать до родини Asparagaceae (Холодкові), порядку Asparagales (Холодкоцвіті) та класу Monocotyledons (Однодольні) (The Angiosperm... 2016; Polygonatum ... 2013).

Для дослідження збирали розкриті квітки та бутони модельних рослин і фіксували у 70\% етанолі. Зовнішню морфологічну будову квітки

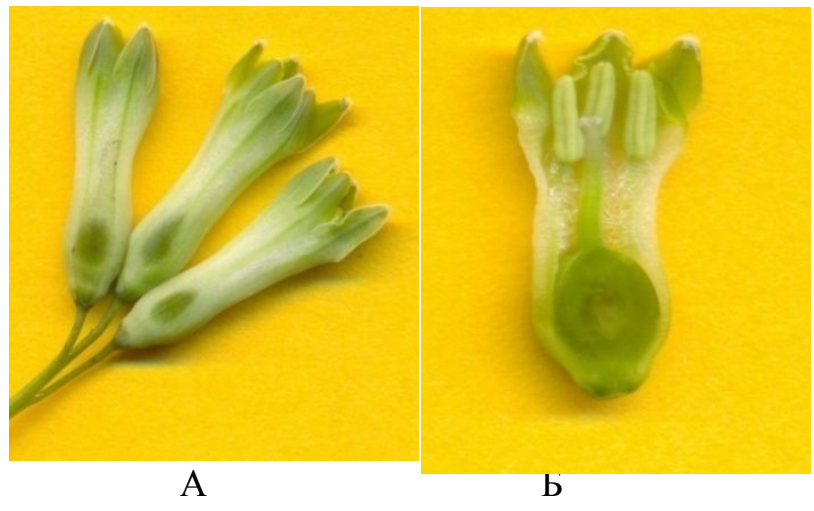

Polygonatum multiflorum (L.) All. вивчали за допомогою стереоскопічного бінокулярного мікроскопа МБС-10. Для дослідження мікроморфології й анатомії квітки для кожного виду виготовили постійні мікроскопічні препарати 5 квіток поперечних зрізів і 5 квіток поздовжніх зрізів. Для виготовлення постійних мікроскопічних препаратів зрізів квітки використані класичні методики просочення матеріалу парафіном. Зрізи заключали у канадський бальзам. Мікроскопічні дослідження проведені за допомогою мікроскопа LABOVAL 4 фірми CARL ZEISS (Jena) та мікроскопа Olympus SZ 61. Мікрофотографії виготовлені за допомогою мікрофотонасадки CARL ZEISS (Jena) 3 використанням перехідного кільця до дзеркальної цифрової фотокамери CANON та фотонасадки Olympus SC 30. Визначення масштабу проводили шляхом фотографування. Рисунки зрізів виготовляли за їхніми мікрофотографіями.

\section{Результати й обговорення}

У пазухах листків видів роду Polygonatum Mill. на квітконіжках розташовані по 3-5 квіток. Квіти зібрані у суцвіття китиця. Квіти мають просту віночковидну, актиноморфну оцвітину. Віночок трубчастий, зрослопелюстковий, утворений шістьма білими пелюстками. Він звужений над зівом, вгорі трохи розширений, 3 шістьма зеленуватими, відігнутими на кінцях зубцями, які вгорі 3 внутрішньої сторони короткоопушені. Ці рослини $є$ ентомофільними, a саме запилюються довгохоботковими джмелями.

Андроцей складається 3 шести тичинок. Тичинкові нитки голі або із зубчиками. Пиляки лінійні, за довжиною майже рівні 3 тичинковими нитками (рис. 1).

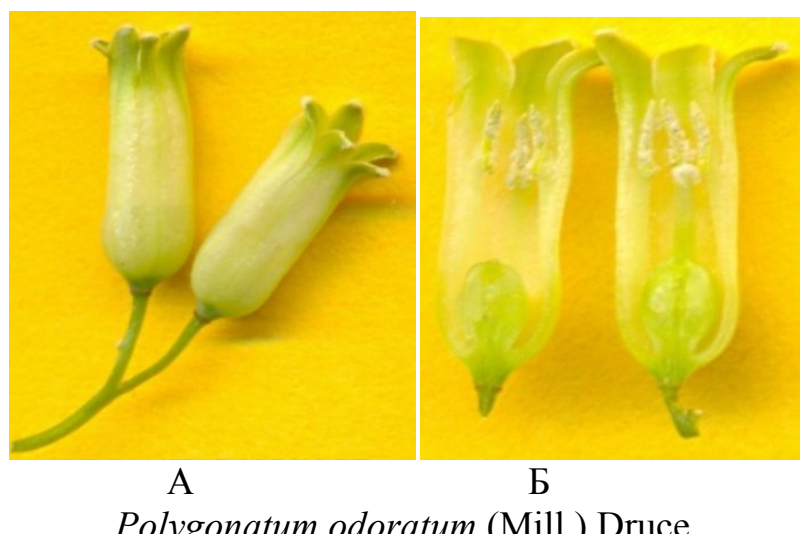

Polygonatum odoratum (Mill.) Druce 


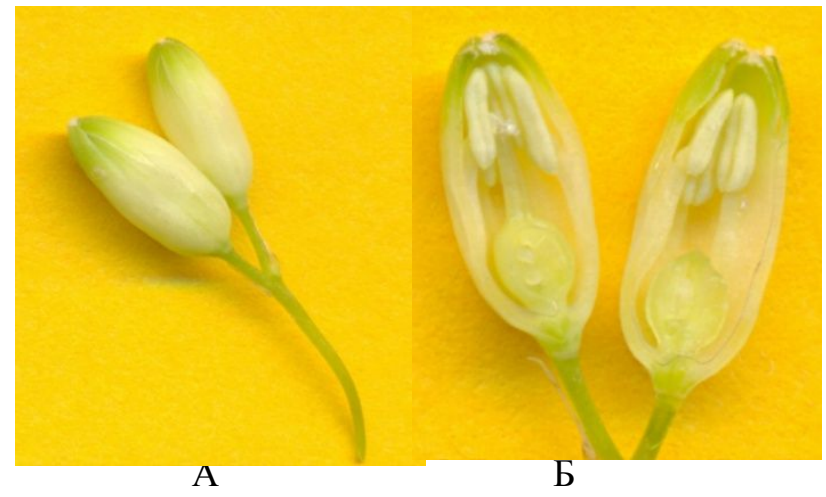

Polygonatum verticillatum (L.) All.

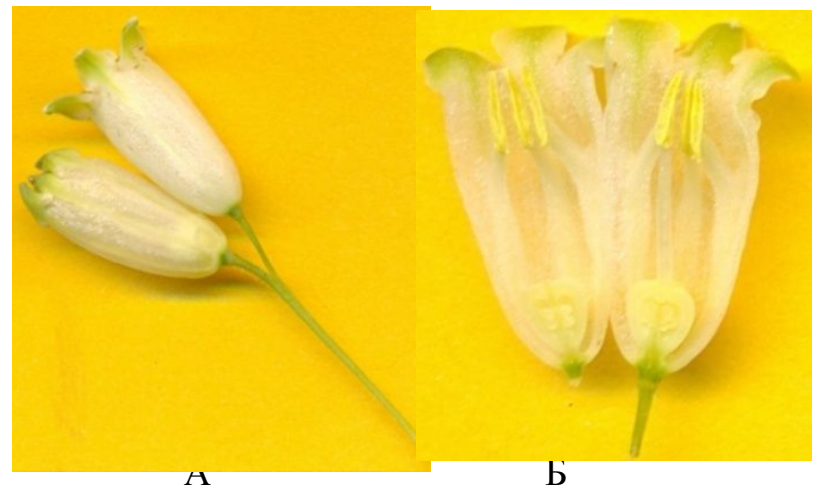

Polygonatum latifolium Desf.

Рис. 1. Квітка видів роду Polygonatum Mill.: А - загальний вигляд; Б - поздовжній розріз.

Пиляк видів роду Polygonatum Mill. (рис. 2) складається $з$ двох половинок - тек, у кожній 3 яких утворюється по два пилкових гнізда. Пластинка, яка з'єднує між собою половинки пиляка - в'язальце. У пилкових гніздах, що вистелені покриваючим шаром - тапетумом, знаходиться археспоріальна тканина, 3 якої, в результаті мікроспорогенезу, утворюються мікроспори. Пиляк вкритий одношаровим епідермісом, зовнішні стінки клітин якого вкриті суцільною плівочкою кутикули. Під епідермісом виділяється шар клітин 3 сітчастими потовщеннями клітинних оболонок - це ендотецій, або фіброзний шар. За його участі відкриваються пилкові гнізда. I3 внутрішнього боку їх вкриває вистилаючий шар. Гнізда пиляка заповнені пилковими зернами.

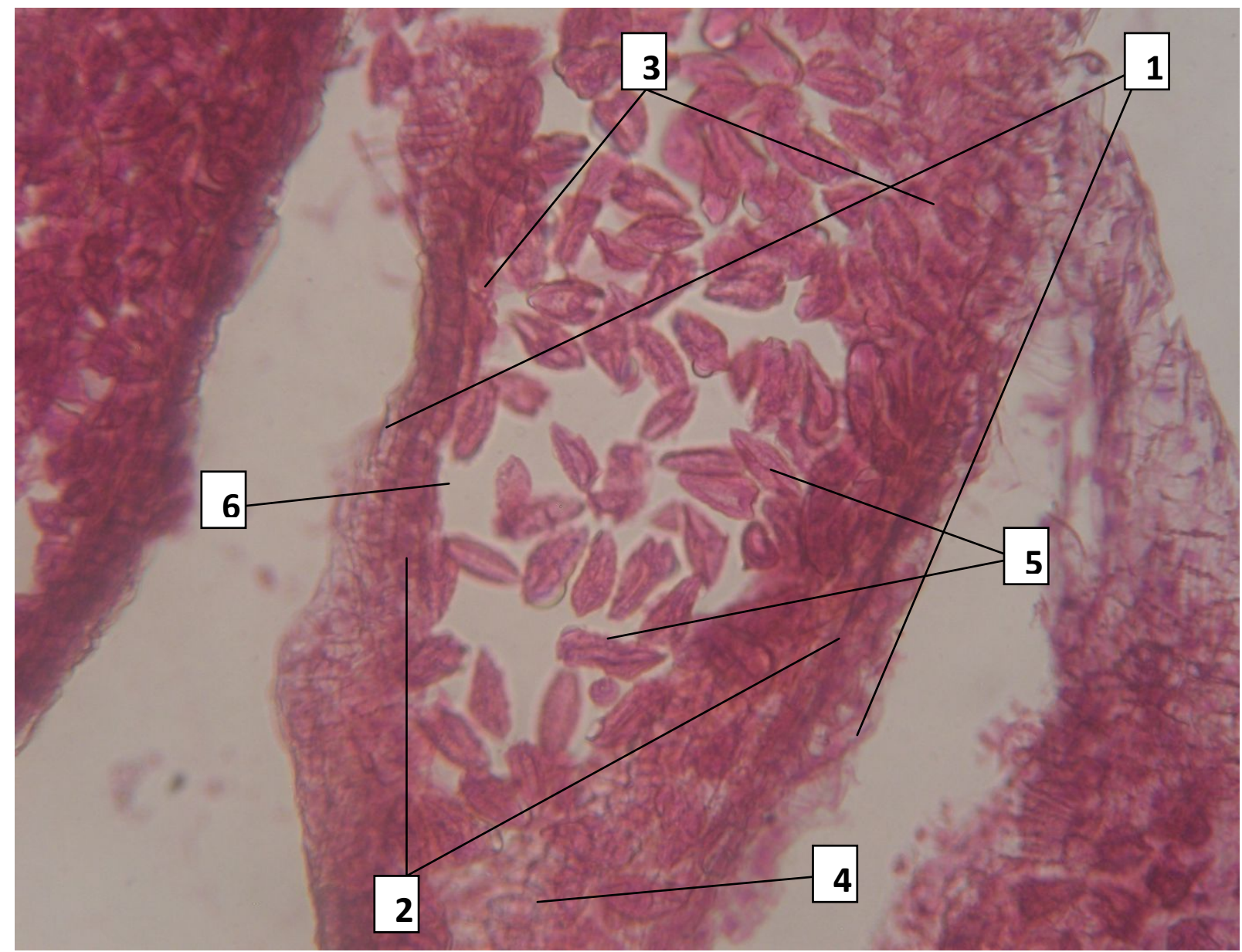

Рис. 2. Будова пиляка 3 пилком Polygonatum multiflorum (L.) All. (мікрофото: $\times 1000$ ): 1 - епідерміс; 2 фіброзний шар; 3 - вистилаючий шар; 4 - паренхіма в'язальця; 5 - пилок; 6 - пилкове гніздо. 
Пилкові зерна (рис. 3) видів роду Polygonatum Mill. двоборозні (дисулькатні), еліпсоїдальні, в обрисі 3 екватора еліптичні, полярна вісь 26,7-28,0 мкм, екваторіальний діаметр 11,0-15,4 мкм, борозна (sulcus) розширена, іiі краї рівні, кінці борозни майже доходять до полюсів. Скульптура екзини сітчаста або дрібно-сітчаста. Стінки комірок вузькі, гладенькі, майже рівні, дно комірок рівне. Особливості скульптури екзини більш виражені на проксимальній стороні пилкового зерна (Melnichenko, Mylenka 2014).
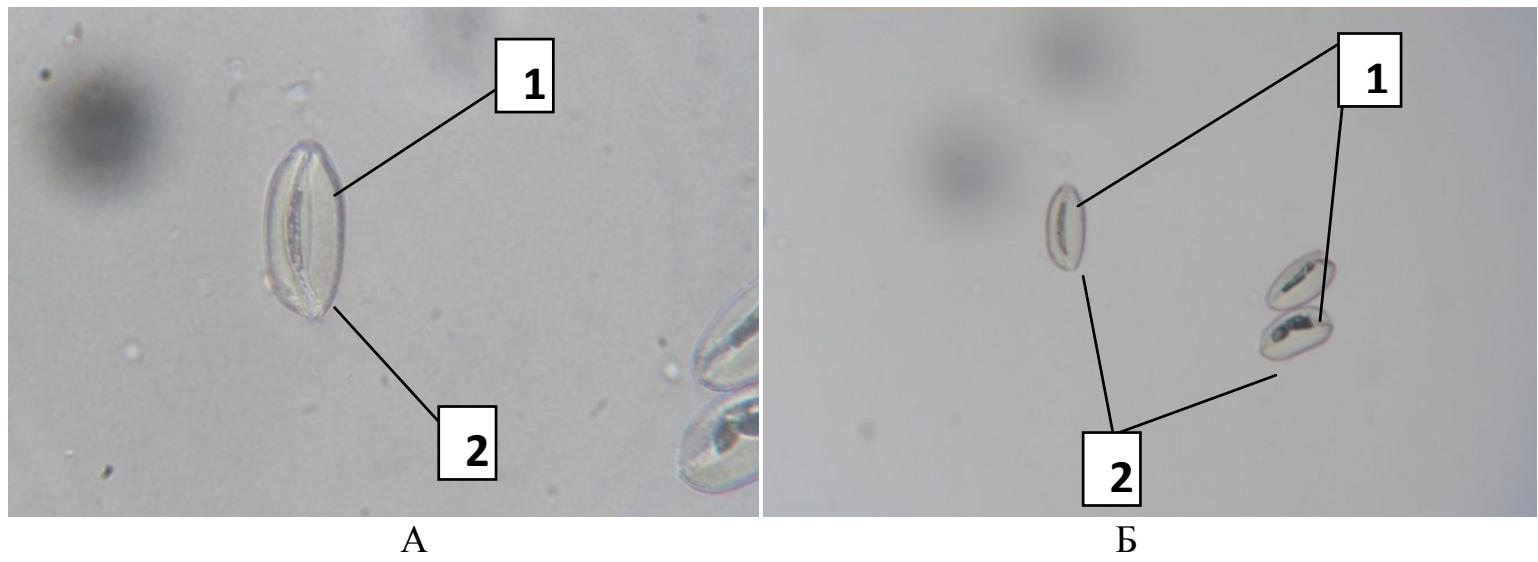

Рис. 3. Пилок видів роду Polygonatum Mill.: А - пилок (зб.: ×1000); Б - пилок $(\times 800)$ : 1 - двоборозність (дисулькатність); 2 - екзина.

Маточка у видів роду Polygonatum Mill. одна 3 ниткоподібним стовпчиком і трилопатевою приймочкою. Зав'язь тригніздна, верхня, тобто розташована вільно на квітколожі. Гінецей синкарпний, який утворився в результаті зростання трьох плодолистків. У гніздах зав'язі розташовані насінні зачатки (рис. 4). Кожен 3 яких складається 3 покривів - інтегументів і багатоклітинної частини - нуцелуса.

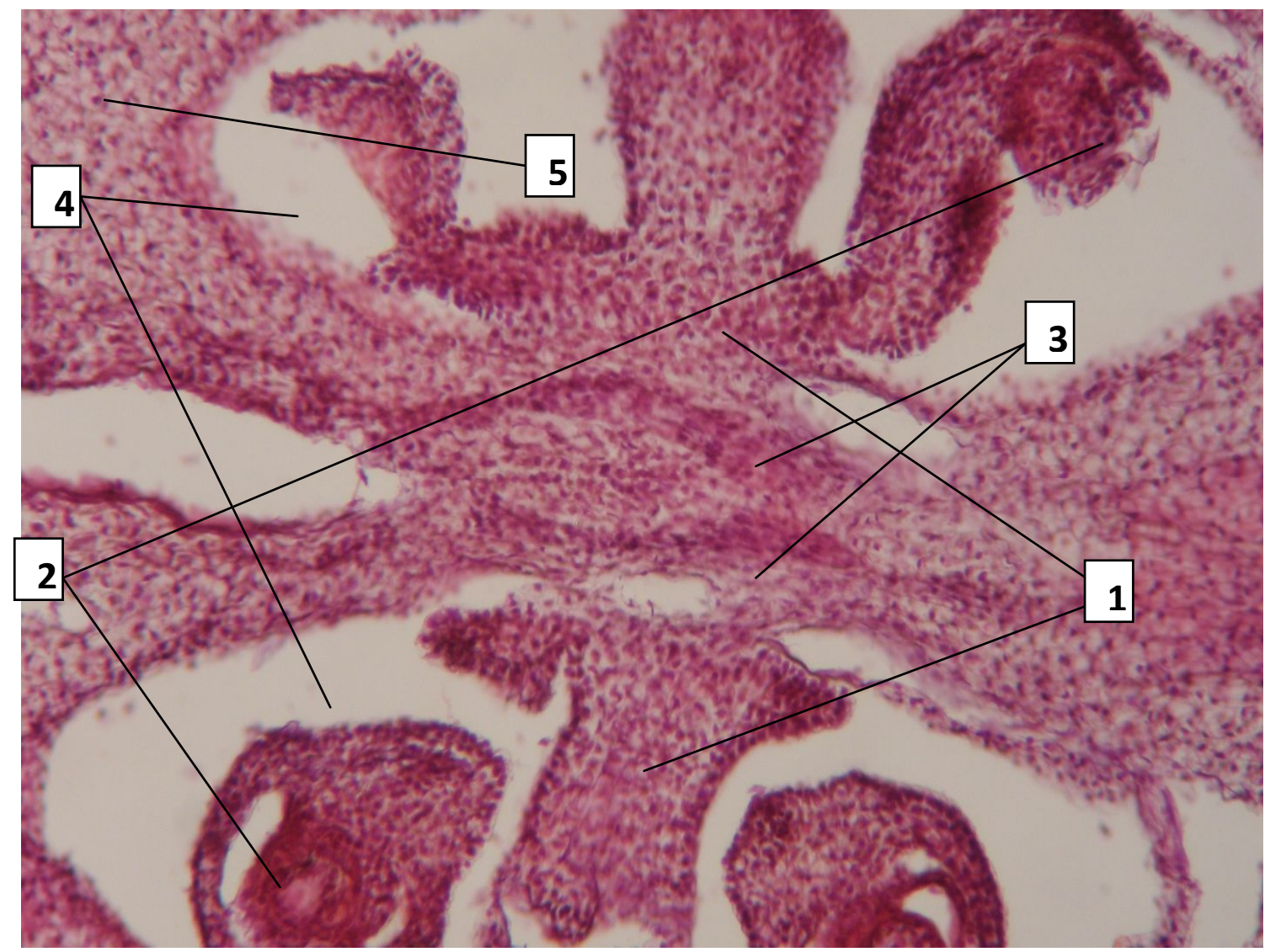

Рис. 4. Насінний зачаток Polygonatum multiflorum (L.) All. (мікрофото: ×1000): 1 - фунікулюс; 2 насінний зачаток; 3 - плацента; 4 - гніздо; 5 - стінка зав'язі. 
Для видів роду Polygonatum Mill. характерний центрально-кутовий тип плацентації. Насінний зачаток складається 3 нуцелуса (ядра в широкому розумінні), вкритого одним або двома шарами інтегументів (покривів) (багатоклітинні шари), кінці яких 3 одного боку насінного зачатка, не зростаючись, утворюють вузький канал - мікропіле, або пилковхід (рис. 5). Через мікропіле пилкова трубка проникає до зародкового мішка (Hontova 2014; Hryhora 2004).

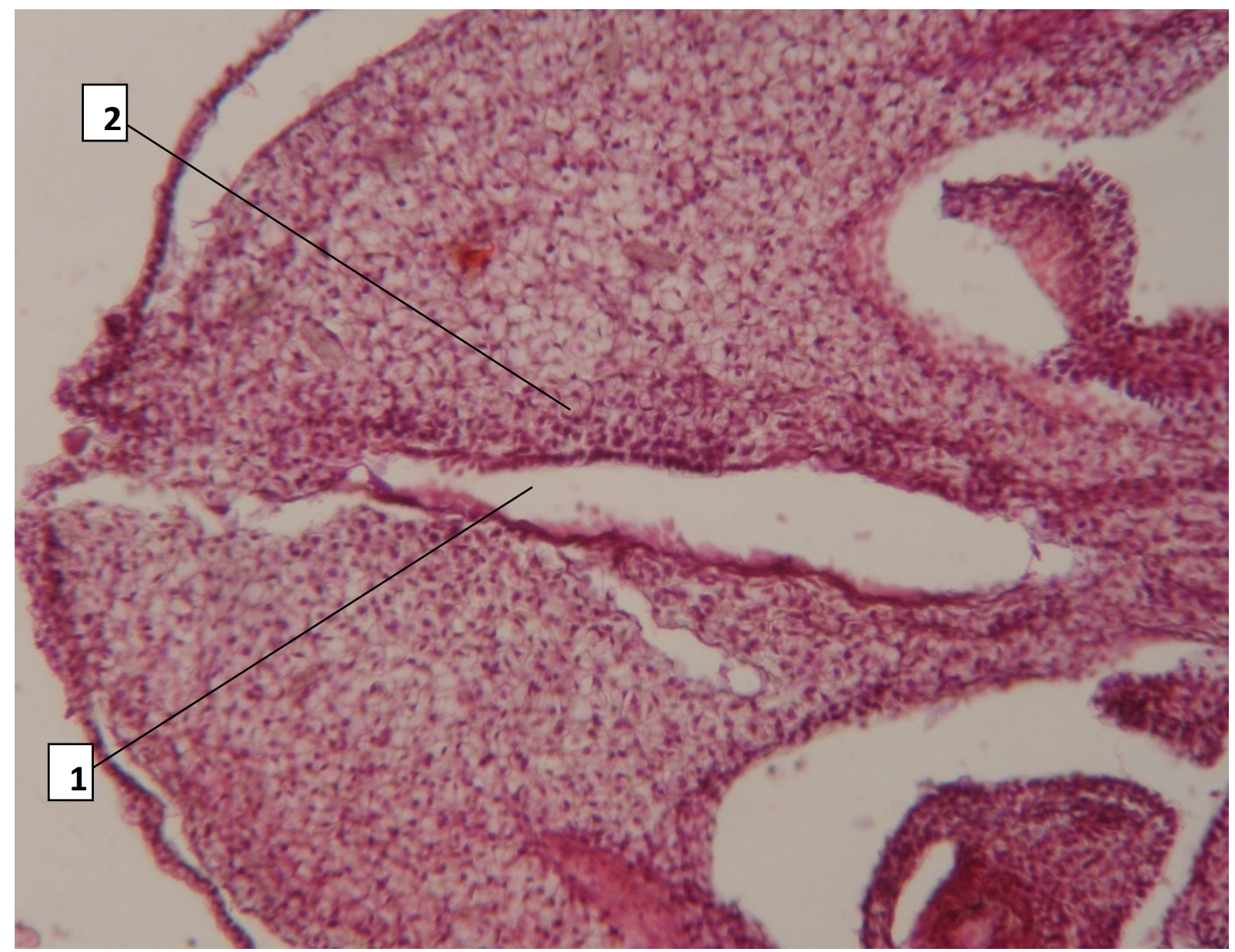

Рис. 5. Пилковхід Polygonatum multiflorum (L.) All. (мікрофото: ×1000): 1 - мікропіле; 2 - інтегумент.

Зав'язь видів роду Polygonatum Mill. має складний розвиток i будову. В $\dddot{11}$ гніздах розміщені насінні зачатки, в яких 3 археспоріальної клітини шляхом мейозу формуються тетради мегаспор. Одна 3 них розвивається в зародковий мішок (жіночий гаметофіт). При подвійному заплідненні із диплоїдної зиготи, що виникла в результаті злиття яйцеклітини і спермія, розвивається зародок, а 3 триплоїдної клітини, яка виникла після злиття центральної клітини і спермія, формується ендосперм. Як наслідок із насінного зачатка утворюється насінина, а із зав'язі - плід.

Плід більшості видів роду Polygonatum Mill. - соковита багатонасінна синьо-чорна ягода діаметром близько $1 \mathrm{~cm}$, а у Polygonatum verticillatum (L.) All. - фіолетово-червона ягода (рис. 6). Цвіте у травні - червні.
Плід утворюється із зав'язі, але в його утворенні можуть брати участь різні частини квітки (оцвітина, основи тичинкових ниток). Оплодень (перикарпій) складається 3 трьох шарів: зовнішнього - екзокарпію або епікарпію, середнього - мезокарпію і внутрішнього ендокарпію (рис. 7) (Hryhora 2004).

Насіння видів роду Polygonatum Mill. переважно яйцеподібної або кулястої форми, вкрите міцною насіннєвою оболонкою, яка щільно прилягає до ендосперму. Кількість насінин у плоді коливається від 1 до 11 (рис. 8). Насіння Polygonatum multiflorum (L.) All. належить до великого, оскільки маса 1000 насінин становить 27,3 г для всіх досліджуваних популяцій (Riznychuk 2009). 


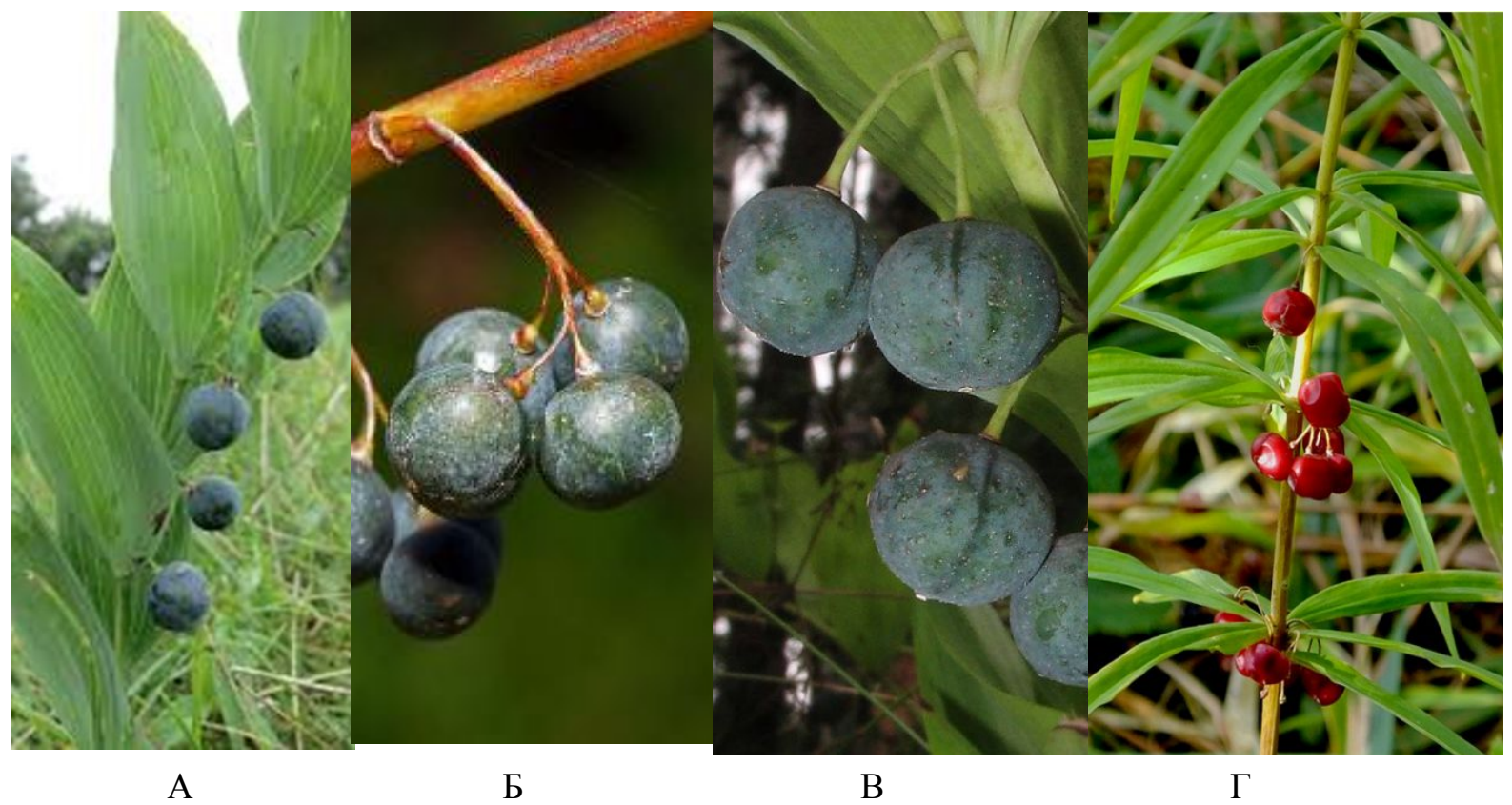

Рис. 6. Плодоношення видів роду Polygonatum Mill. (А - Polygonatum odoratum (Mill.) Druce, Б - Polygonatum multiflorum (L.) All., B - Polygonatum latifolium Desf., $\Gamma$ - Polygonatum verticilatum (L.) All.).

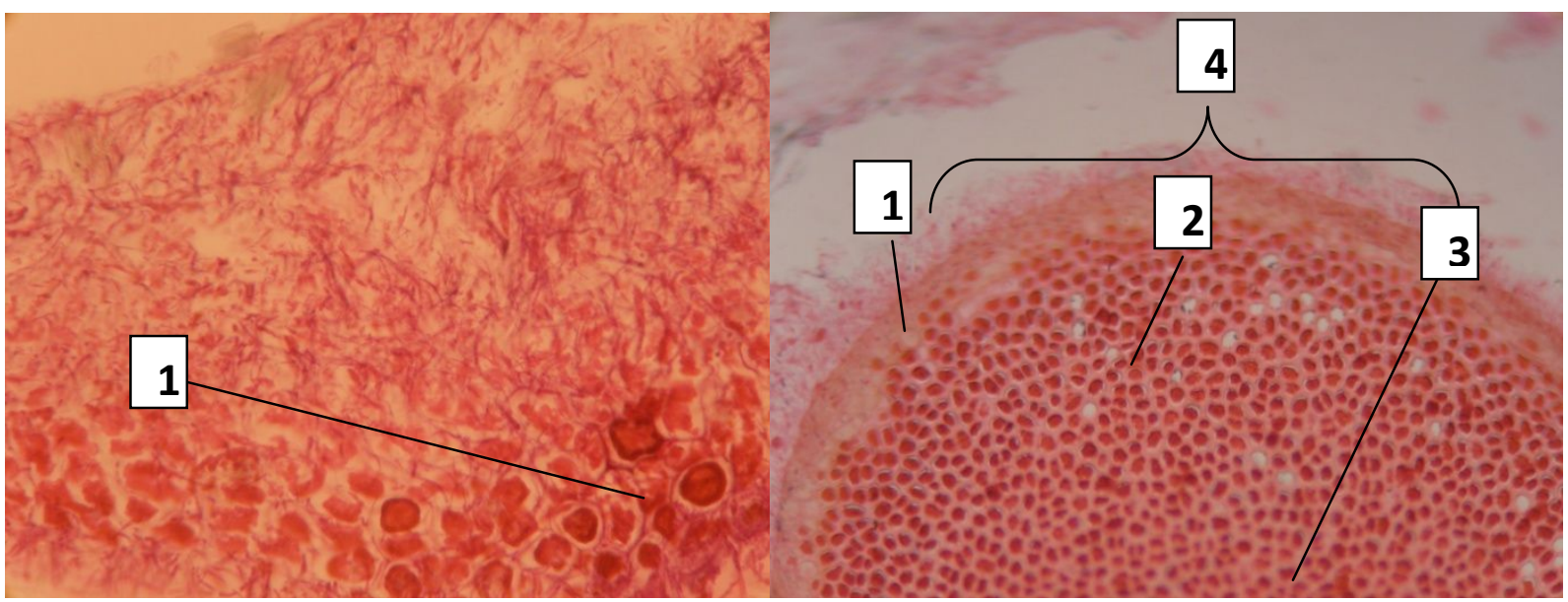

A

Б

Рис. 7. A - Гістофото екзокарпію Polygonatum multiflorum (L.) All. (мікрофото: $\times 1000$ ): 1 - екзокарпій; Б - Будова плоду Polygonatum multiflorum (L.) All. (мікрофото: ×1000): 1 - екзокарпій; 2 - мезокарпій; 3 - ендокарпій; 4 - перикарпій.

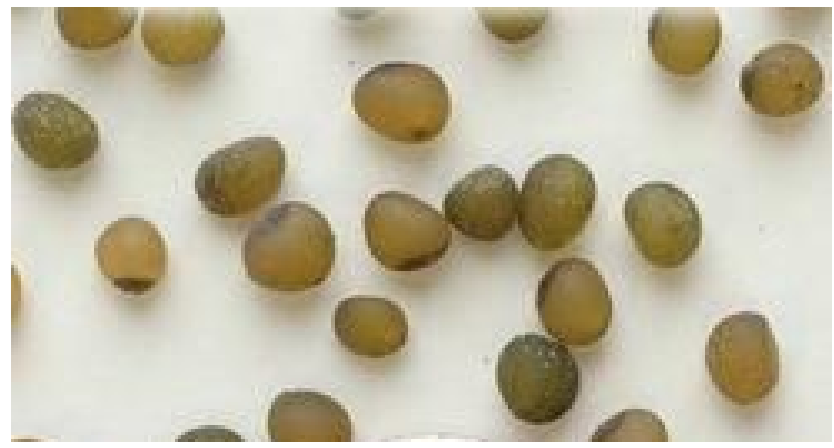

Рис. 8. Насіння Polygonatum multiflorum (L.) All. 


\section{Висновки}

У зав'язі видів роду Polygonatum Mill. наявні сильно потовщені основа і дах зав'язі, які містять базальну та апікальну частини видовженого септального нектарника відповідно. Стовпчик у видів 3 септальним нектарником сформований лише за рахунок постгенітального злипання плодолистків. Типовою ознакою квітки $\epsilon$ шість листочків оцвітини, розміщених у двох колах, як правило не диференційовані на пелюстки і чашолистки, шість тичинок у двох колах і три плодолистки. Тичинки, прирослі до квіткової трубки оцвітини. Насінні зачатки розміщені завжди у гемісимплікатній зоні гінецея в парній кількості, по два, основа та дах зав'язі потовщені. У досліджуваних видів гемі симплікатна зона відсутня, наявні синасцидіатна, гемісимплікатна фертильна і асимплікатна зони.
THE ANGIOSPERM PHYLOGENY GROUP (2016) An update of the Angiosperm Phylogeny Group classification for the orders and families of flowering plants: APG IV. Botanical Journal of the Linnean Society, 181(1): 1-20. doi:10.1111/boj.12385

MELNICHENKO, G., MYLENKA, M. (2014) Quantitative and qualitative dynamics of airborne allergenic pollen concentration in the urban ecosystem of Ivano-Frankivsrk (western Ukraine). Journal of International Scientific Publications: Ecology and Safety, 8: 312-319.

MOSYAKIN, S.L., FEDORONCHUK, M.M. (1999) Vascular Plants of Ukraine. A nomenclatural checklist. M.G. Kholodny Institute of Botany, Kyiv.

RIZNYCHUK, N.I. (2017) Special features of the dimensional structure and life strategy of coenopopulations of Polygonatum multiflorum L. (All.) in the biotops of Precarpathians (Western Ukraine). Austrian Journal of Technical and Natural Sciences, 3-4: 3-6.

POLYGONATUM ODORATUM (Mill.) In: The Plant List (2013). Version 1.1. Available from: http://www.theplantlist.org/tpl1.1/record/kew-

284008 (accessed 1st January).

HONTOVA, T.M., RUDENKO, V.P, SIRA, L.M., HAPONENEKO, V.P., SERBIN, A.H., OPROSHANS'KA, T.V., MASHTALER, V.V., MALA, O.S., ROMANOVA, S.V. (2014) Anatomia i morfolohia roslyn u rysunkah [Plant anatomy and morphology in figures]. NFaU, Kharkiv. (in Ukrainian)

HRYHORA, I.M., YAKUBENKO, B.Ye, ALEINIKOV, I.M., LUSHPA, V.I., SHABAROVA S.I., TSARENKO, P.M., PIDIURA O.I. (2004) Botanika. Praktykum [Botany. Practice]. Vydavnychyi tsentr NAU, Kyiv. (in Ukrainian).

RIZNYCHUK, N.I. (2009) Nasinneva produktyvnist' Polygonatum multiflorum L. na Prylukvyns'kiy vysochyni (Peredkarpattia) [Seeds productivity of the Polygonatum multiflorum L. on the Prylukvynska highlands (Peredcarpattia)]. Visnyk Kyivs'koho natsional'noho universytetu imeni Tarasa Shevchenka. Introduktsiia ta zberezhennia roslynnoho riznomanittia, 24: 163-165. (in Ukrainian) 